\title{
Analysis of Changes in Land Use Patterns Pursuant to the Conversion of Agricultural Land to Non-Agricultural Use in the Context of the Sustainable Development of the Malopolska Region
}

\author{
Malgorzata Busko ${ }^{1, *}$ (D) and Beata Szafranska ${ }^{2}$ \\ 1 Department of Department of Integrated Geodesy and Cartography, AGH University of Science and \\ Technology, 30059 Krakow, Poland \\ 2 Department of Agriculture and Geodesy, Marshal's Office of the Malopolska Province, 30017 Krakow, \\ Poland; Beata.Szafranska@umwm.pl \\ * Correspondence: mbusko@agh.edu.pl; Tel.: +48-608-017-172
}

Received: 7 November 2017; Accepted: 5 January 2018; Published: 9 January 2018

\begin{abstract}
This research paper presents the results of analyses that address the direction in which the issue of land use in Malopolska has been heading in recent years. The authors formulated the thesis that changes occurring in the use of agricultural land are advanced and, despite its legal protection, this land is continuously subjected to permanent conversion to non-agricultural use year by year. Verification of the thesis was carried out using taxonomic analyses. As a result, it was proven that as much as $68 \%$ of the land converted to non-agricultural use in the study period was earmarked for residential use. Importantly, as much as $19 \%$ of these areas are of the best quality classes, i.e., classes I and II, which account for a mere 7\% of all agricultural land in Malopolska. Another 79\% of the converted agricultural land belonged to the mid class, i.e., class III, which-at the time of writing-represents only $26 \%$ in the Malopolska Province. This data demonstrates that the best lands of the Malopolska Province, which belonged to classes I, II and III (i.e., top quality arable soils), were irreversibly degraded by their conversion to non-agricultural use. The paper proposes systemic solutions supporting the decision-making process of administrative bodies aimed at agricultural land protection.
\end{abstract}

Keywords: sustainable development; agricultural land; conversion of agricultural land to non-agricultural use; changes of agricultural land use

\section{Introduction}

The concept of sustainable development first appeared in Polish legislation in 2001 when the Act on Environmental Protection was adopted [1]. Pursuant to Art. 3, Section 50 of the act, sustainable development is understood as integrated political, social and economic activities aimed at ensuring the safety of natural processes while satisfying the current needs of citizens. Therefore, it is important to retain equilibrium between the possibility of the present generation to develop and to guarantee the right of future generations to a natural environment. In this way, reference was made to the Report [2] in which the definition of sustainable development appeared.

In order to be able to implement sustainable development of the economy, land and society, sustainable development should be based on an integrated system of data collection that would be up-to-date, reliable and accessible [3,4]. One such system is the Land Administration System (LAS) - a multi-faceted system for collecting data from various public records (including real estate cadastre) and spatial information systems [5]. The integration of these systems and records should ensure interoperability within the structure of spatial information $[6,7]$. 
Literature provides various methods for evaluating the implementation of sustainable development [8-11]; however, the data on parcels of land and on land use, included in various public records, always constitute the basis of the analysis [12-15].

The proper use of land and the protection of agricultural and forest land is frequently considered to be a local environmental issue [16,17]. In the study [18] it has been demonstrated that, also in northern Italy, suburban areas are particularly vulnerable to the conversion from agricultural to non-agricultural use. The problem of such conversion in the vicinity of large cities has also been discussed in the paper [19]. The phenomenon of land conversion from agricultural to non-agricultural use has been defined there as "urban expansion" and estimated at about $40 \%$ of all agricultural lands surrounding large cities. However, only land uses and not land quality classes, have been analysed in these papers.

This issue, however, is becoming a global one and applies to many countries. In the paper [20] it has been emphasized that it is necessary to develop further case studies for other regions in Europe regarding agriculture decline due to urban expansion. Our research paper addresses this specific need by presenting reliable results of changes in land use in Malopolska.

The analysis of the conversion of agricultural land to non-agricultural use must be based on the current legal system. Pertaining to agricultural and forest lands located in Poland, the legal status is regulated by the Act on the Protection of Agricultural and Forest Land of 1995 [21]. This act stipulates the principles and determines the procedures, i.e., the sequence of individual actions aimed at converting land to non-agricultural and non-forest use. Firstly, the land must be earmarked as non-agricultural and non-forest in the local zoning plan. Secondly, a decision is issued specifying the conditions of such a conversion. The final stage includes the actual conversion of agricultural land carried out by the owner (holder), i.e., the abandonment of the existing land use. The legal analysis on the protection of agricultural land located in urban areas in Poland was carried out in [22]. Research studies on the conversion of agricultural land to non-agricultural use and the protection of agricultural land have been conducted in Reference [23] but only in reference to one county-Zwolen in the Mazowieckie province. In Reference [24], changes in land use for the Małopolska province have been analysed but with the use of Corine Land Cover. For this reason, these analyses do not contain information on land quality classes, which is essential in our research paper.

The development of industry is inevitable in today's world. However, it is necessary to ensure that the practice and prospects for the development of industry are ecologically sound [25-27]. Rapid and uncontrolled urbanisation can lead to the occurrence of a phenomenon which, in the literature, is referred to as the emergence and development of so-called 'urban villages'. Such a phenomenon is observed in China, for example [28-30] —-this has nothing to do with sustainable development, so it is essential to take measures to counteract it.

Pro-ecological protection of agricultural and forest land in Poland is the subject of various interesting studies. As far as forest land is concerned, the paper [31] deals with the question of afforestation of land in the period 1995-2013, with particular emphasis on the effect of Poland's accession to the European Union in 2004 on the implementation of environmental actions. Legal bases and principles related to the protection of agricultural land in Poland are discussed in [32]. It should be expected that the adopted national policy would implement a comprehensive system of the use of agricultural land and principles of the division of agricultural land for agricultural and non-agricultural purposes [33].

The use of agricultural land for purely agricultural purposes is also closely related to subsidies for agricultural production from the European Union funds [34,35]. However, excessive development of agricultural production, without concern for sustainable development regarding residents' needs, may also lead to numerous problems, as demonstrated in [36].

Many inhabitants of Poland, including the inhabitants of the Malopolska Province, are faced with the selection of their place of residence. They can choose between a heavily developed urban area, such as the capital of the province - the city of Krakow—or other large cities of the region, such as Bochnia, 
Brzesko, Tarnow, Nowy Sacz etc. and the countryside around these larger cities. One of the criteria that must be taken into account while making a choice is whether the network of roads facilitates or inhibits daily commuting to cities for employment or educational purposes [37]. Such surveys analysing satisfaction relating to place of residence within or outside the city have been conducted in Chicago [38]. These studies demonstrated that the quality of transportation roads is an important factor when choosing a place of residence and significantly affects the level of residents' satisfaction [39].

Developers of zoning plans, architects and designers need to understand that an appropriate communication system, the development of access roads and their quality make positive contributions to the ecological development of the local community [40]. Successful implementation of sustainable development in the aspect of roads and communication not only improves the economic aspects of life of the inhabitants but also ensures a healthier environment. It is important that local communities are actively involved in the process of sustainable land management regardless of whether it concerns highly developed or developing countries [41,42]. With the commencement of the industrialisation process in developing countries, the character of the agricultural space is changing into invested areas. Rural areas are subject to significant changes, as for example, in China $[43,44]$. The optimisation of the conversion of agricultural land to industrial land in rural areas forms the bases for the sustainable development of rural areas. Moreover, the importance of the restructuring of rural areas also plays a significant role in agriculture [45-47].

The international literature describes research studies on the commercialisation of rural areas using qualitative methods [48], quantitative methods $[49,50]$ and using a mixed approach. This paper will utilise a mixed approach but with a significant part of quantitative research being based on taxonomy, with particular reference to the Ward method.

The main objective of this research paper is to analyse the state of changes in land use which have taken place in land development in southern Poland, within the Malopolska Province, over the last seven years. The analysis was carried out with respect to:

- determining the size of land converted to non-agricultural use,

- determining the directions of changes in the use of land converted to non-agricultural use,

- determining the quality classes of land converted to non-agricultural use.

\section{Materials and Methods}

The research study will identify the areas (counties) in the Malopolska province in which the land of the best quality classes is converted to non-agricultural use; the research will also specify the direction of land use changes. The main source of data is the register of land and buildings maintained and updated by the counties. Pursuant to the regulation on the register of land and building [51], it is uniform across the public land registry database for the whole country.

It should be emphasised that the Malopolska province is a particularly difficult case as far as data acquisition for the analysis of record data is concerned. The province consists of 22 counties and 182 communes covering 4,516,496 record parcels. In many counties of the Malopolska province, geodetic and cartographic documentation databases are still maintained in an analogue form. The graphic part, i.e., the cadastral map for rural areas, is maintained in the vector form for only approximately $35 \%$ of the province area and for the remaining rural areas, it is still a map in an analogue form. A large share of the descriptive part of the record data utilised for the preparation of this paper (225 files in Appendix C and 7 files in Appendix D) is analogue (non-electronic). Although the data on the size of land converted to non-agricultural use collected by the Marshal of the province is available for a period longer than seven years, the key data for this article was that from the districts regarding land quality classes. The data for the whole province exists only for the period 2010-2016. Thus, it is not possible to perform a long-term analysis in the Malopolska province. For statistical analyses, creating graphs, data operations and data transformation, the authors used the Statistica software. 


\subsection{Materials for the Analysis}

The research area covered the Malopolska province, one of 16 provinces in Poland (Figure 1). The Malopolska province covers an area of $15,183 \mathrm{~km}^{2}$, which accounts for $4.9 \%$ of the country's territory and ranks the region in 12th place with regard to area. Administrative divisions divide the province into 22 counties, consisting of 182 communes: 46 municipal-rural communes, 14 municipalities and 122 rural communes (Figure 2). This province was selected for the analysis because it has one of the largest areas of land converted annually to non-agricultural use in Poland.

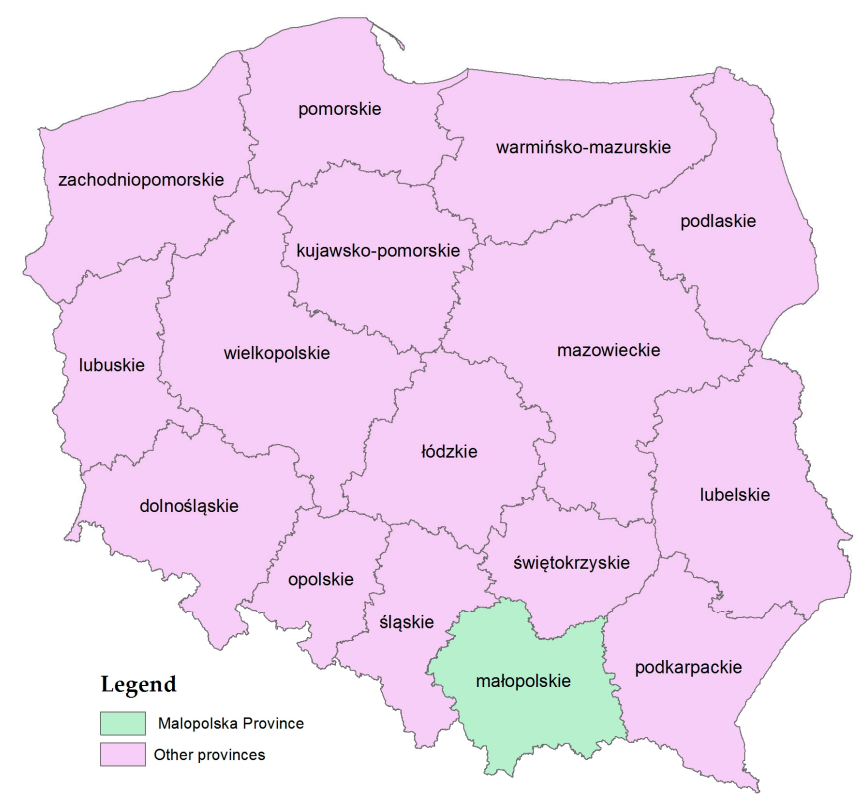

Figure 1. Administrative division of Poland.

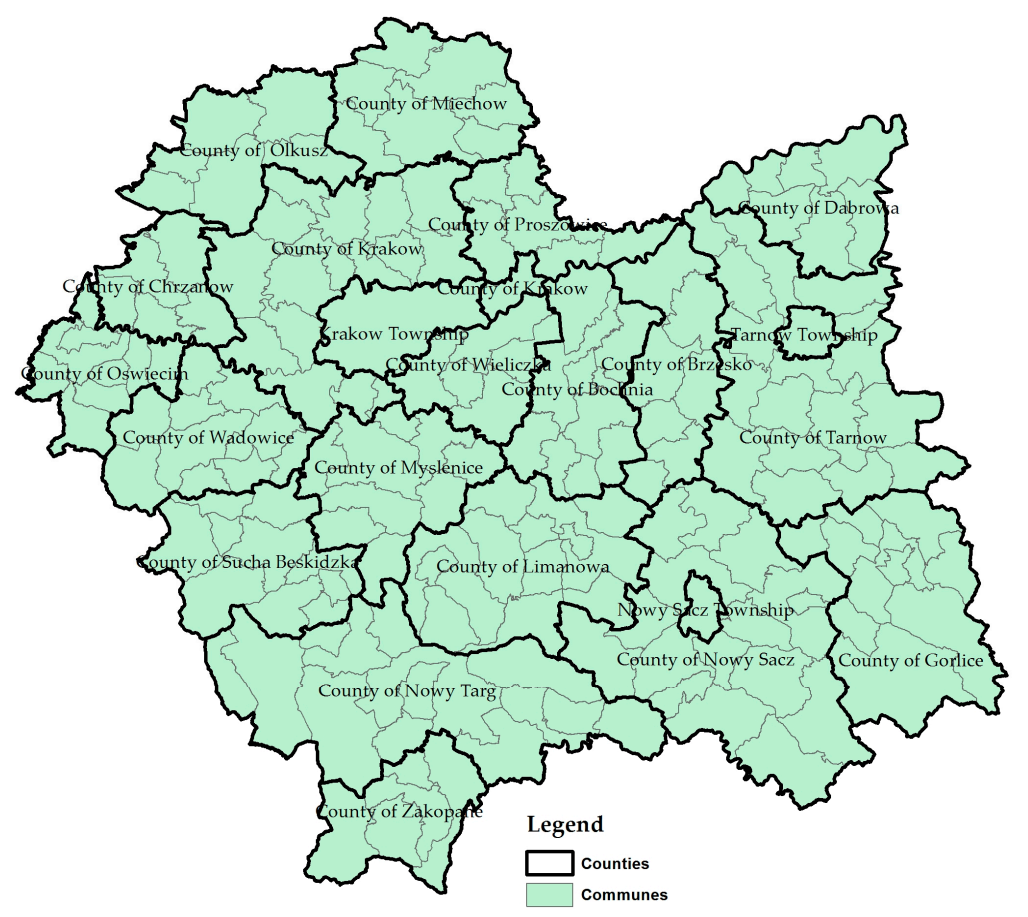

Figure 2. Administrative division of the Malopolska province. 
Malopolska is characterised by a great variety of landscape features, geological structure, climatic, hydrological and soil conditions. Agricultural land is the main form of land use in the Malopolska province. By 2015 , it covered a total of 537,500 ha, constituting $81.0 \%$ of the total area of agricultural holdings in the province. The vast majority ( $96.8 \%$ of the total agricultural land) belonged to individual farms [52]. The most favourable soil conditions for agricultural production are located in the eastern and northern parts of the province and in the northern part of the Carpathian foothills. Over recent years, there has been a systematic decline in the area of land devoted to agricultural use.

\subsection{Research Methods_Taxonomic Analysis as a Tool for Regionalisation}

The region is a spatial concept referring to a specifically separated territory, which, due to the relative homogeneity of its characteristics and its connections, differs from the surrounding areas [53]. Regionalisation is a specific procedure for the division of space into regions, i.e., smaller and relatively homogeneous areas which, due to the accepted criteria, create a specific whole which is separated by strictly defined boundaries. Regionalisation can be carried out according to one or several criteria and its most important task is to reduce the number of spatial units. Generally, the objective of regionalisation is to create a smaller number of regions which would be continuous units and maximally uniform internally as far as a given set of characteristics is concerned, from a certain number of spatial units with specific characteristics. The administrative division into regions supports effective management and functioning of the organisational unit [54].

Getting to know the degree of spatial variability of the counties in the Malopolska province provides a lot of valuable information - this is useful for monitoring changes occurring in land use in the whole province. A set of attributes of selected mapped elements of geographical space contribute to the complexity and diversity of the natural environment, these include: the area of agricultural land in the Malopolska province divided according to their quality classes in the years 2010-2016; the area of agricultural land converted to non-agricultural land use; the purpose of its conversion; the percentage of specific quality classes of land being converted to non-agricultural use; other attributes discussed by the authors in this paper. The multidimensional statistics, developed by Jan Czekanowski and Zdzisław Hellwig, deal with the analysis of the multi-faceted phenomena and objects. At the beginning of the twentieth century, Czekanowski's first work was published [55]. His research initiated the widespread use of numerical taxonomy in anthropology, agriculture, geography and the environment. According to Kukula [56], one of the main concepts in the theory of regionalisation is to treat regionalisation as a sort of classification based on the criterion of the homogeneity of spatial objects. Usually, one of the taxonomic procedures allows the distinguishing of more homogeneous groups of objects resulting from the similarity of the selected set of attributes.

In defining the notion of regional statistics, Mlodak [57] identifies all the statistical activities undertaken in relation to specific regions as research subjects and the term 'the region' is understood as a specific territory whose area is determined by arbitrarily defined administrative boundaries. Taxonomy as a science- the main idea of which is aggregation, analysis and organization of objects described by numerous statistical variables-plays an important role in studying the efficiency of results obtained by regional statistics and the complex variability of territorial units, relative to the occurring phenomena. According to Mlodak, determining the direction of the grouping process involves a necessity to determine the grouping hierarchy. Hierarchical and non-hierarchical methods can be distinguished here. The characteristic attributes of hierarchical methods are the levels of integration or disintegration of groups.

The algorithms implementing division of the set into subsets, so that these subsets contain the most similar objects, can be divided into two main groups [58,59]: hierarchical and non-hierarchical ones. Hierarchical methods include the methods as follows: of the closest neighbourhood, the furthest neighbourhood, the gravity centres, median, the group average, the weighted group average, the Ward method. In these methods, trees are created as part of clusters by grouping objects having similar attributes. Initially, the procedure assumes that each object constitutes a separate subgroup. By finding 
the shortest distance, the elements which should be merged in the next step of the agglomeration are highlighted.

One of the most popular and most widely used agglomeration methods is the Ward method-this was used in this study. Proposed by J.H. Ward, this method differs from all others because it uses an ANOVA to estimate the distance between clusters. This method is aimed at minimising the sum of squares of deviations within the clusters. At each stage, of all possible merging pairs of clusters, the one which produces a cluster with minimal variation as a result of merging is chosen. The measure of such variation relative to the mean values is the expression ESS (Error Sum of Squares), which is defined by the following formula:

$$
E S S=\sum_{i=1}^{k}\left(x_{i}-\bar{x}\right)^{2}
$$

where $x_{i}$ is the value of the segmentation variable for the $i$-th object, $\bar{x}$ is the mean value of the segmentation variable and $k$ is the number of objects in the cluster.

This method is considered to be very effective, although it is aimed at creating small-sized clusters. Its computational effect is a tree in the form of a specific dendrite called a dendrogram. The threshold value has been determined so as to ensure the identification of a proper number of classes of the counties to create larger areas with homogeneous features according to the principle of regionalisation. With regard to the research methods for taxonomic analyses, it should be emphasised that one of the co-authors, in her doctoral dissertation, analysed the hierarchical and non-hierarchical grouping methods in great detail, proving that Ward's method is simple but sufficiently effective.

\section{Results}

The description and categorisation of soils is facilitated by their systematic classification which takes into account the causes of the formation and similarities between specific soil units. Figure 3 shows the structure of the soils by quality class for the entire province at the beginning of the research period (2010).

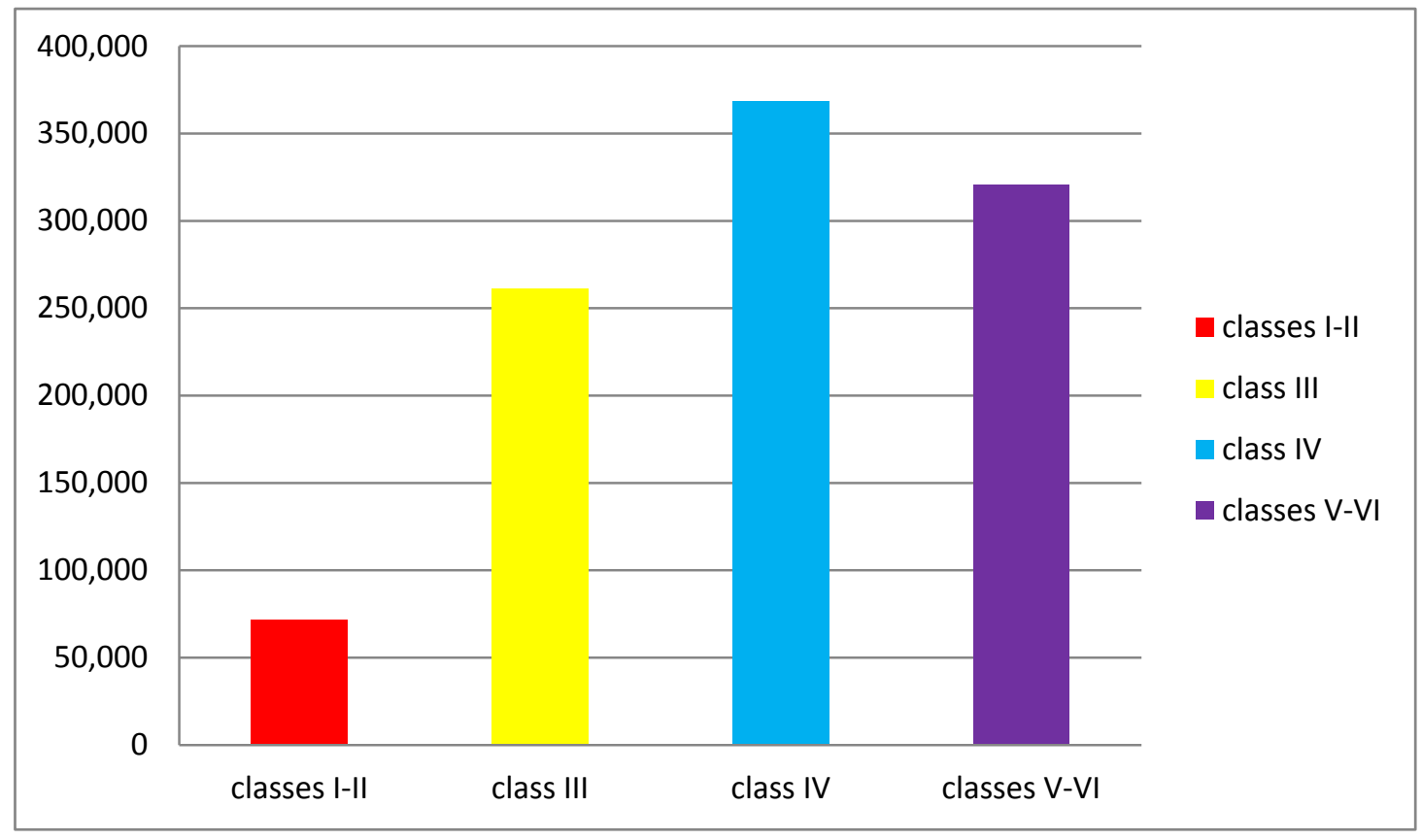

Figure 3. Surface areas of agricultural land use in the Malopolska province in 2010 divided into quality classes and expressed in hectares (ha).

Soil classification in Poland covers both agricultural land as well as forest land. The agricultural land, especially the best and very good soils (of classes I and II), are particularly valuable due to their 
nutrient content for plants, their soil structure and environmental values. The share of the soils which belong to quality classes I and II in the total area of the agricultural land in the province is only $7 \%$ (Figure 3). The best soils (according to the classification) can be found in the northern and central parts of the province. $26 \%$ of all agricultural land use is made up of soils of classes IIIa and IIIb, i.e., good soils, occurring in slightly worse physiographic conditions than soils of classes I and II. They also have significantly worse physical and chemical properties than classes I and II soils. The groundwater level fluctuates more and the crops are dependent upon the weather. Some soils are periodically too dry, others may be too wet at times. They may also be susceptible to erosion. As much as $36 \%$ of soils in the Malopolska province belong to classes IVa and IVb, i.e., medium quality soils. These are heavy soils, most often too dry or too wet, too heavy for cultivation, or located in poor physiographic conditions, such as strong declines, eroded hills or depressions. As much as $31 \%$ of all the soils in the province are poor and the poorest soils, i.e., those which belong to classes V and VI. These soils are not very fertile, they are barely productive, the crops are very poor and their successful growth is uncertain. Such soils are frequently earmarked for afforestation or other non-agricultural purposes. The advantage of the region is its clean environment, so despite the low quality of the soils resulting from the mountainous and piedmont landscape, there are favourable conditions for the development of healthy food production in the southern part of the province [60].

The sources of the data presented in the bar charts (Figures 3 and 4) are the databases of the register of land and buildings maintained by the counties (Appendix C). The bar chart in Figure 3 illustrates the general structure of the soil quality classes for the entire province, while Figure 4 shows the division of the agricultural land into quality classes within individual counties. This bar chart is based on the data from 225 files (Appendix C). The data contained in Table A1 (Appendix A) and in the bar charts (Figures 3 and 4) is the synthetic input data for the analyses carried out later in this paper.

With respect to the discussed initial situation, the authors of the article have conducted an analysis of the agricultural land in the Malopolska province which has been annually converted to non-agricultural use during the seven years between 2010 and 2016. 


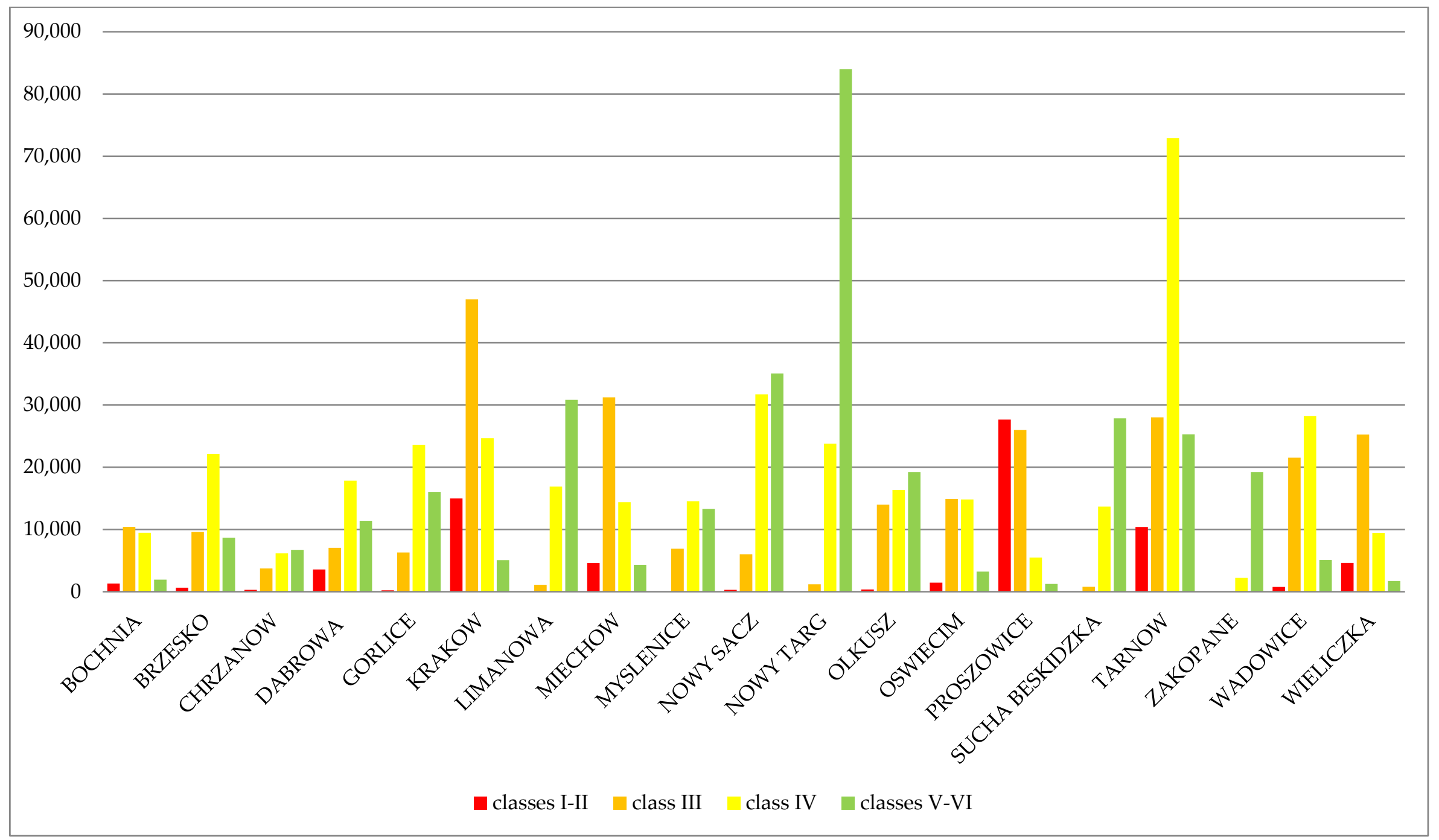

Figure 4. Surface area of agricultural land uses within specific quality classes in the individual counties of the Malopolska province in 2010 expressed in hectares (ha). 
3.1. Groups of Counties Similar in Terms of Quality of the Soils at the Initial Stage of the Research (2010)

Based on the bar chart in Figure 4, the dendrogram presented in Figure A1 (Appendix B) was developed using the Ward method. This allowed the distinguishing of eight groups of counties $(\mathrm{A}-\mathrm{H})$ according to their similar attributes (quality classes). The size of the area of the soils of the best quality class was adopted as a leading attribute.

The vertical axis of the dendrogram represents the county numbers according to Table A1, while the horizontal axis is a dimensionless number representing the distances of clusters (regions). The red line is a fixed threshold value that provides the appropriate number of classes.

Figure 5 demonstrates the area of the Malopolska province divided into smaller administrative units (counties). Groups of similar counties are marked on the map with different colours (Figure 5). Groups of the counties which were identified as having the largest surface area of the best quality classes (class I and class II) at the initial stage of the research, i.e., in 2010, are marked in green. It is clearly visible that the northern part of the region has the best soil conditions. Among these counties, the first to be mentioned is Proszowice, followed by Krakow and Tarnow. Then, the next are Wieliczka, Wadowice and Miechow. The poorest soils are located in the southern part of the region, i.e., in the counties of Sucha Beskidzka, Limanowa, Nowy Sacz, Zakopane and Nowy Targ. This is closely related to physiographic conditions and topography because these areas belong to the mountainous and piedmont landscape.

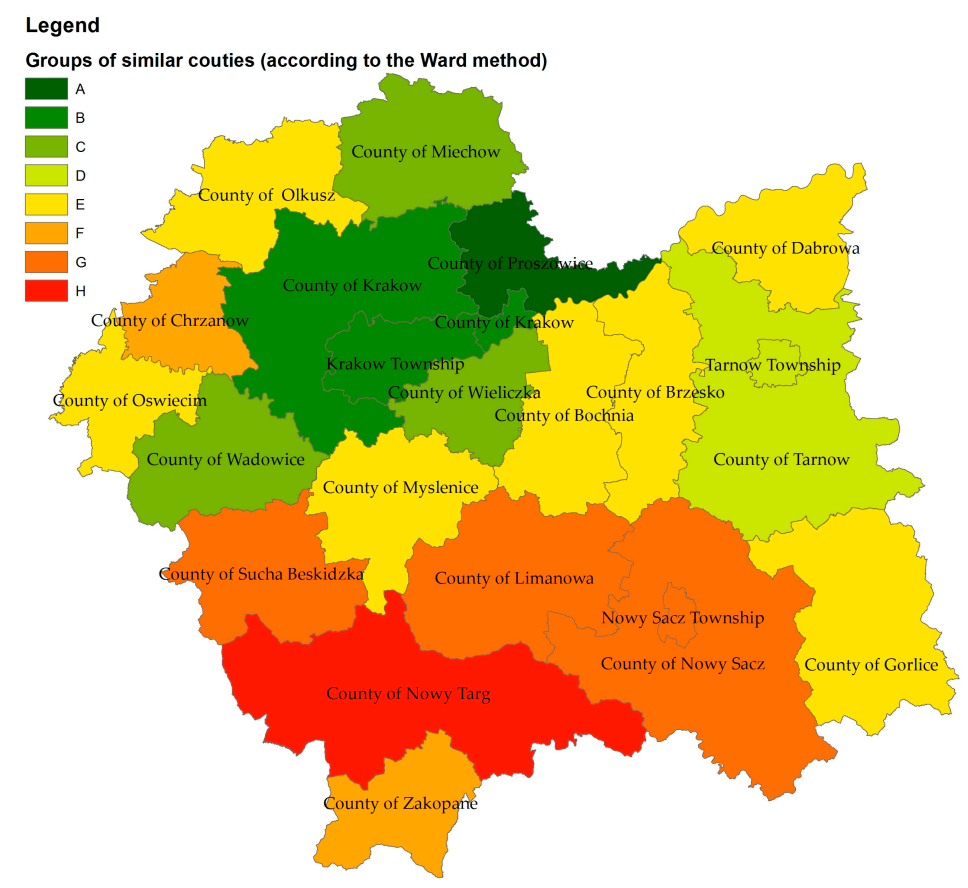

Figure 5. Map of groups of similar counties (according to the Ward method) with regard to surface area of quality classes I-VI in individual counties of the Malopolska province as of 1 January 2010.

\subsection{Groups of Counties Similar with Regard to Size of Agricultural Land Converted to Non-Agricultural Use}

The analysis carried out later in this paper aimed to identify the areas of the Malopolska province where the greatest degradation of the best classes of land occurred as a result of converting agricultural land to non-agricultural use. It will also be important to define the specific purpose of these land use changes. Additionally, it will be essential to assess whether the development of the areas can be described as sustainable or whether it will simply result in the deprivation of the soil of the most valuable natural values, leading to its irreversible degradation. 
Figure 6 illustrates the trend of land use changes for the whole province, from agricultural to non-agricultural uses, in the analysed period of time.

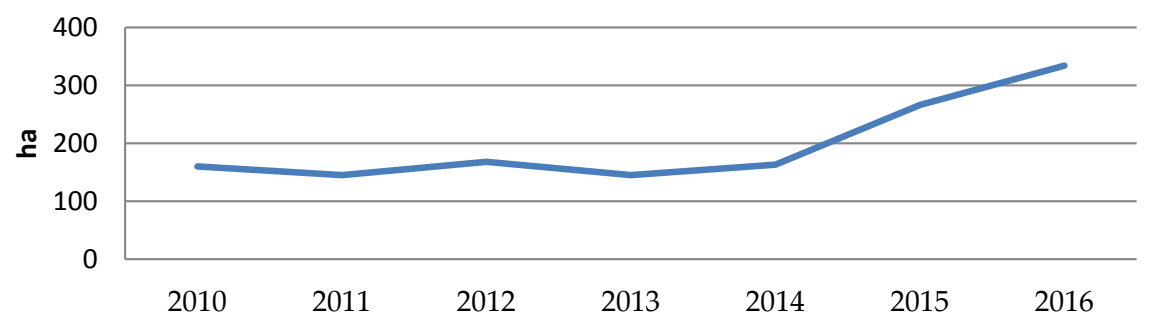

Figure 6. Share of agricultural land converted to non-agricultural use in the Malopolska province between 2010 and 2016 (ha).

Based on the graph in Figure 6, it is noticeable that no significant changes in the conversion of land for non-agricultural use took place in Malopolska in the years 2010-2013. A sharp increase in land conversion since 2014 is related to the economic development of Poland, resulting mainly from the EU investment financing for the country's development activities planned for the years 2014-2020. The studies [61-63] identified price-determining factors affecting the value of agricultural land after Poland's accession to the EU in the regions where agriculture is predominant.

In order to identify details of the changes in land uses presented in a general way on the graph (Figure 6), a detailed analysis of the size of the land converted to non-agricultural use was carried out for all the counties of the region. This allowed the identification of groups of counties similar in terms of the size of land permanently converted to non-agricultural use.

The bar chart (Figure 7) presents the size of the areas compared in Table A2 over the period 2010-2016 for each county of the region.

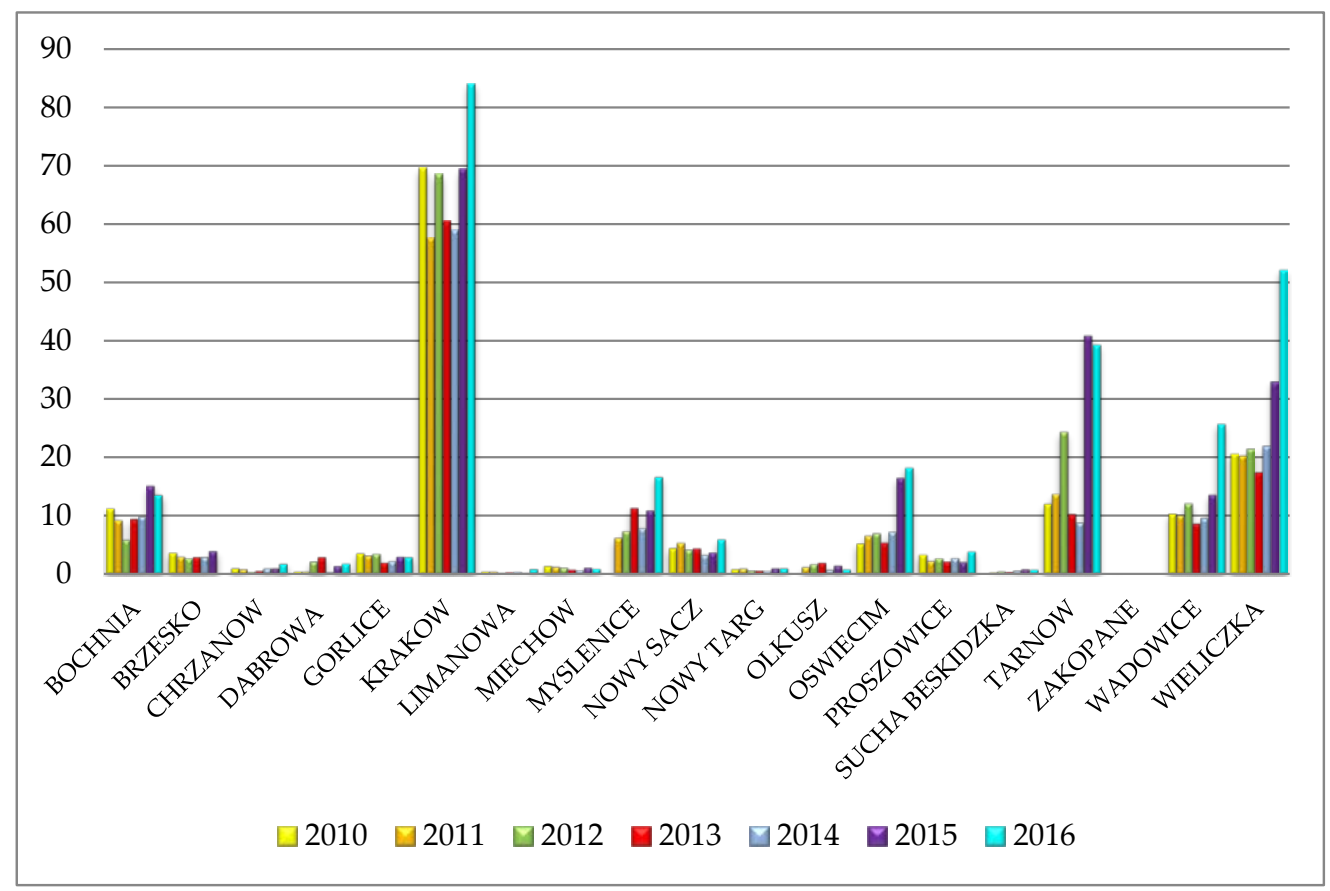

Figure 7. Surface area of the whole agricultural land converted to non-agricultural use in individual counties of the Malopolska province in the years 2010-2016, expressed in hectares (ha) (Appendix D). 
This bar chart (Figure 7) reflects the intensity of changes in land use in each county in individual years. The data from this chart is the input data (characteristics of the counties) in the elaborated dendrogram. The data from Table A2 and Figure 7 is used to compile dendrogram (Figure A2) based on which and using the Ward method, nine groups of counties (A-I) that are similar in terms of the size of agricultural land converted to non-agricultural use are distinguished. The results are presented on the map (Figure 8).

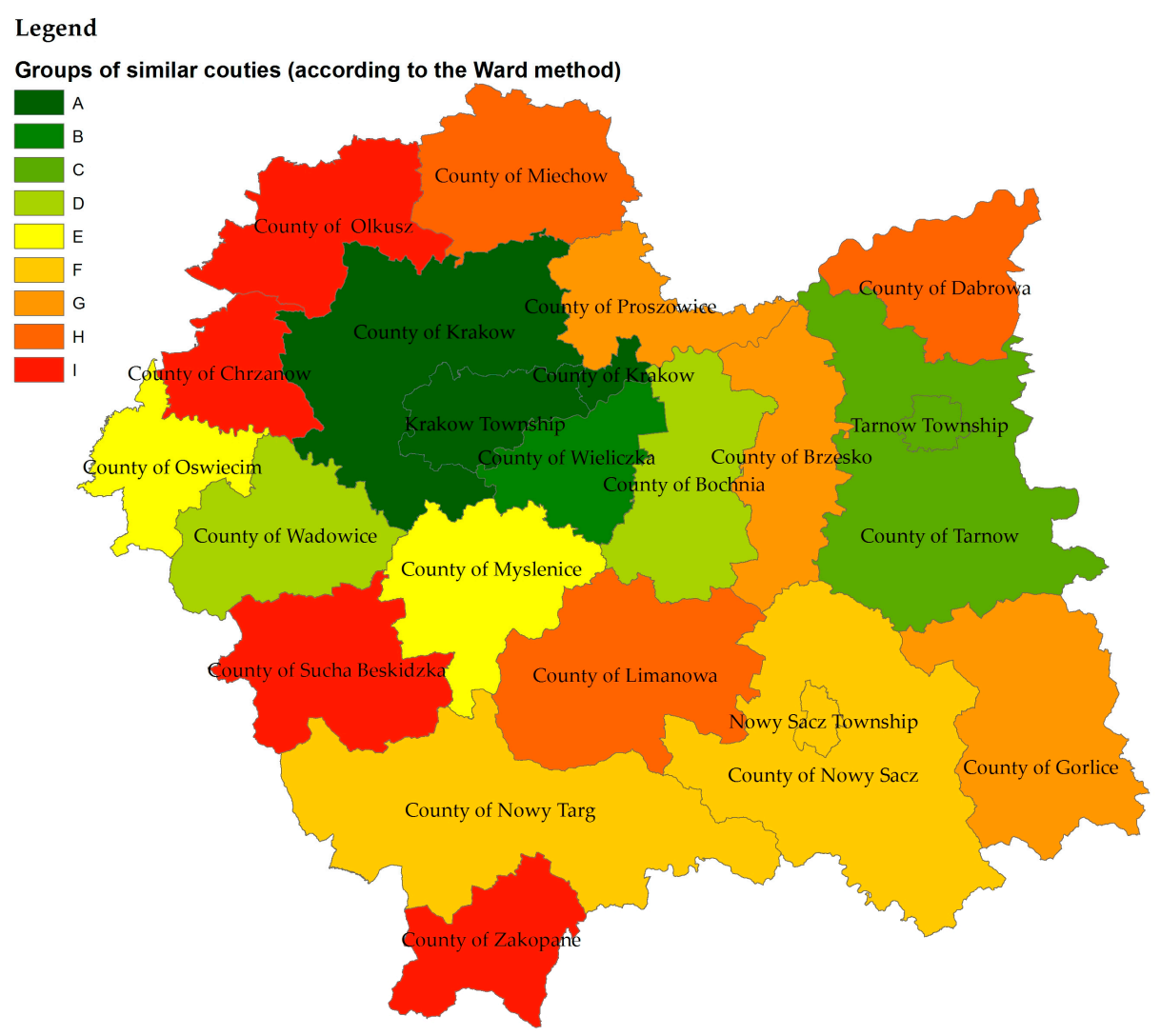

Figure 8. Map of groups of similar counties (according to the Ward method) with regard to surface areas of the whole agricultural land converted to non-agricultural use in individual counties of the Malopolska province in the years 2010-2016, expressed in percent (\%).

The map (Figure 8) geographically presents the information contained in Figure 7, Figure A2 and Table A2, grouping together the counties that are similar in terms of the surface area of the agricultural land converted to non-agricultural use. Thus, it is clear that the persistent degradation of the land is the largest in the counties of Wieliczka, Krakow, Myslenice, Oswiecim, Bochnia and Wadowice. These counties are located in the immediate vicinity of the capital of the region-the city of Krakow. This information forms the grounds to suppose that land use change may be associated with a need to provide housing to the residents of Malopolska. Therefore, the next step in the research is to determine the purpose for which the converted land is earmarked.

\subsection{Specifying the Use of Land Converted to Non-Agricultural Purposes in the Study Period}

The pie chart (Figure 9) illustrates the proportions of intended purposes of the land-use conversions for the entire region. The chart demonstrates that the dominant function of the land converted to non-agricultural use is residential (68\% in the chart). Since the largest share in the land use conversion belongs to residential areas, they are the subject of the analyses later in this research paper. 


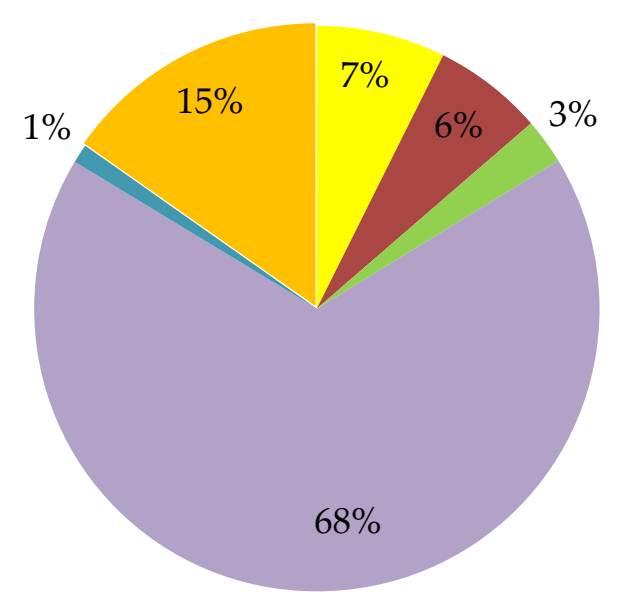

Miscellaneous uses

Industrial areas

Communication areas

Residential areas

Water tanks

Other areas

Figure 9. The purpose of converting agricultural land to non-agricultural use in the Malopolska province in the years 2010-2016, expressed in percent (\%).

3.4. Groups of Counties Similar in Terms of the Quality of Agricultural Land Converted to Non-Agricultural Use and Earmarked for Residential Purposes

Due to the objective of this research, it was necessary to carry out research regarding the definition of quality classes of agricultural land converted to non-agricultural use and earmarked for residential purposes. The pie chart (Figure 10) depicts the percentage share of specific classes of land converted for residential purposes in 2010-2016 for the whole region.

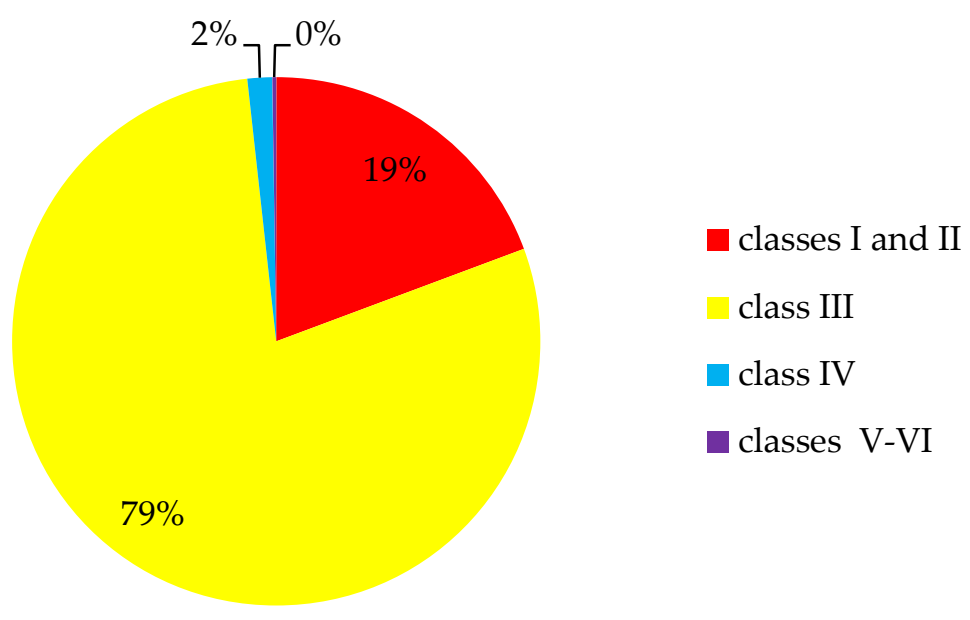

Figure 10. Percentage share of specific classes of land converted for residential purposes in 2010-2016.

The results of the study presented in Figure 10 demonstrate that as much as $79 \%$ of the agricultural land converted to non-agricultural use and earmarked for residential purposes constitute soils of class III, i.e., good soils. The Malopolska province has only $26 \%$ of such soils. Surprisingly, as much as $19 \%$ of the agricultural land converted for residential purposes constitute the best soils (classes I-II). Malopolska has only $7 \%$ of such soils.

Another aspect of the study aims to demonstrate which counties of the region are leaders in converting agricultural land of the best quality classes for residential purposes. For this purpose, the dendrogram (Figure A3) was prepared based on the data contained in Table A3, as shown in the bar chart (Figure 11). 


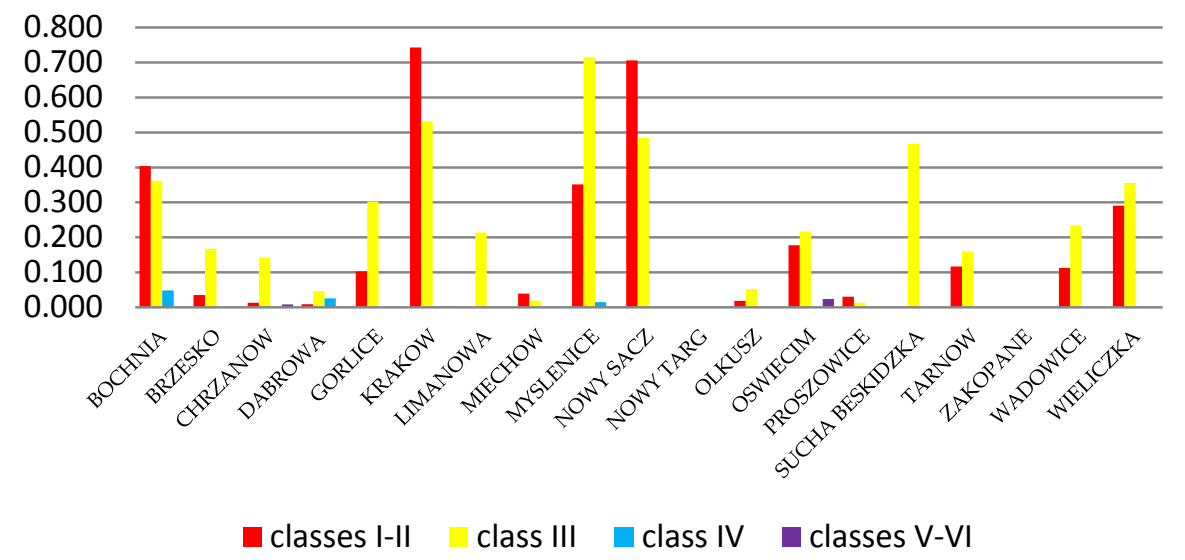

Figure 11. Percentage share of the areas of specific quality classes in the counties of the Malopolska province converted for residential purposes in the years 2010-2016 relative to the total area of individual quality classes in those counties.

The vertical axis of the dendrogram represents the county numbers, according to Table A3, while the horizontal axis-a dimensionless number representing the distances of clusters (regions). The red line is a fixed threshold value that provides the appropriate number of classes (A-F).

Based on the conducted analyses (see Table A3, Figures 11 and A3 for results), the map below (Figure 12) illustrates areas in the region, grouping together counties similar in terms of the quality of their soils converted to non-agricultural use (A-F). The groups of counties converting agricultural land with the best soils and the highest natural values (mainly of quality classes I and II) for residential purposes are marked in green. These include the counties of Krakow, Myslenice, Nowy Sacz and Bochnia. The county of Oswiecim, which also permanently changes the agricultural function of valuable soils (valuation class III) for residential purposes, is highlighted in bright green.

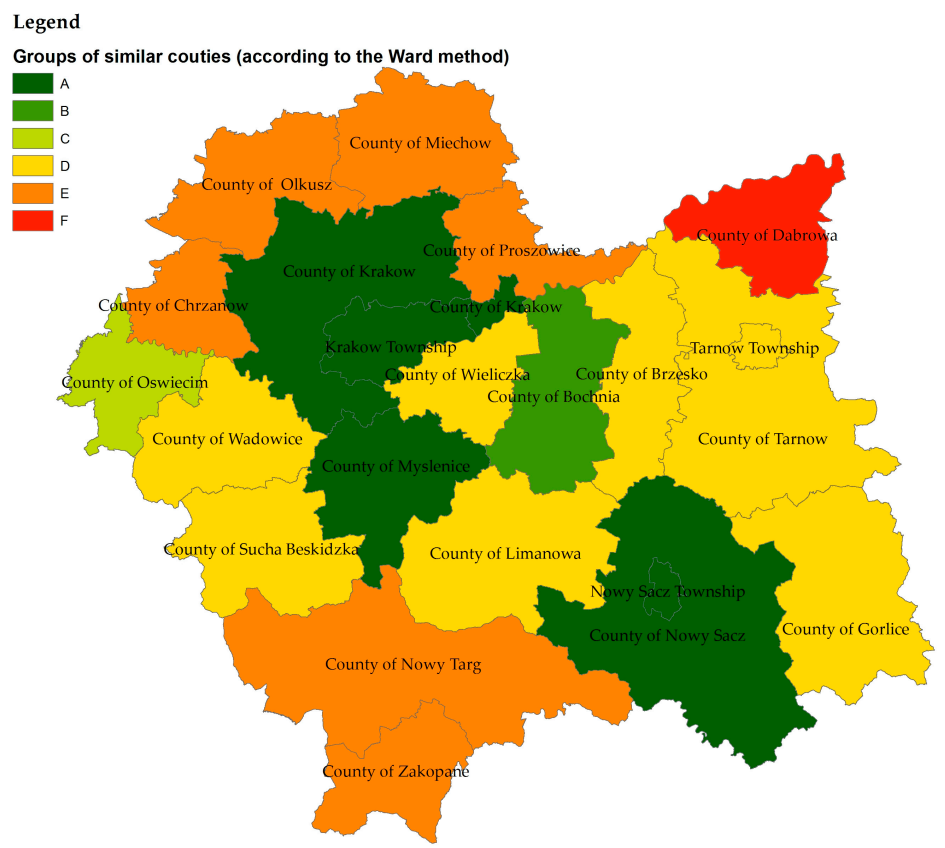

Figure 12. Groups of similar counties (according to the Ward method) with regard to percentage share of the areas of specific quality classes converted for residential purposes in the years 2010-2016 in the counties of the Malopolska province. 


\section{Discussion}

The analysis of changes to land use patterns pursuant to the conversion of agricultural land to non-agricultural use in the context of sustainable development of the region firstly concerned the definition of the natural resources available in Malopolska in terms of quality and suitability of agricultural land. It was important to identify the areas where these soils occur as areas requiring special protection.

Malopolska takes the third place in the country regarding the surface area of agricultural land converted to non-agricultural use in the years 2010-2015, as illustrated in Figure 13.

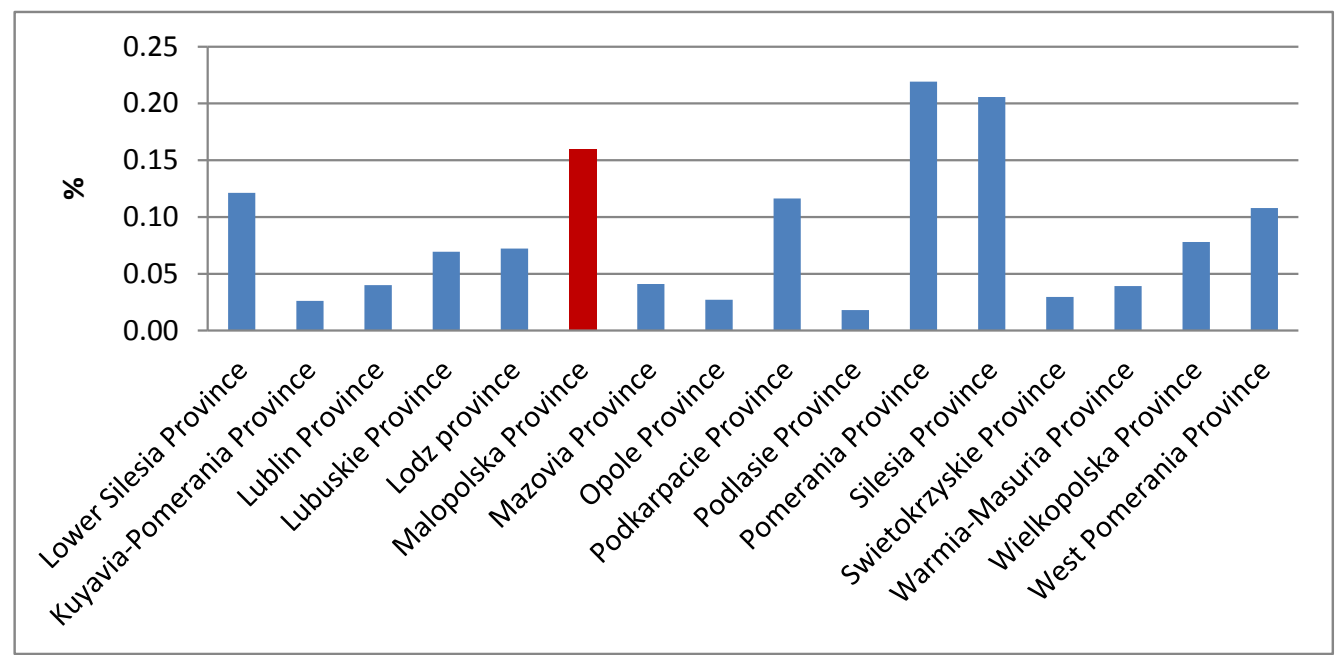

Figure 13. Percentage share of the land converted to non-agricultural use in the years 2010-2015 in Poland. Source: data from the CSO.

The next stage of the research was to determine the size of the land converted to non-agricultural use over the past seven years (i.e., in the period 2010-2016) and to identify the dominant function for which this land was earmarked. The research demonstrates that this function is residential. Bearing in mind that the process of converting agricultural land for residential purposes causes irreversible degradation of land, it was necessary to specify the classes of the converted land. The studies have confirmed that as much as $19 \%$ of the best and very good land (which accounts for only $7 \%$ in the whole region) is destroyed permanently and earmarked for housing. It is exactly these areas that have been indicated by the authors for urgent protection due to their natural values (Figure 5). This is a signal for the regional authorities-the Marshal of the Province, responsible for sustainable development of the region-to stop this direction of change. Taking into account the extremely small percentage of land that is of the best quality classes (classes I and II) in the Malopolska region, there is an urgent need to intensify the protection of this land in the region's policy. Land use planning should be modified so that the most valuable areas are protected and medium-quality soils (classes IVa and IVb) or poor and the poorest (classes V and VI) are earmarked for residential purposes. These soils are not very fertile, barely productive, the crops are very poor and their successful growth is uncertain.

The results of the analyses carried out in this paper were expressed in percent to illustrate the scale of changes in the conversion of agricultural land for residential purposes relative to the total resources of land classes in individual counties of the region.

According to the research presented in [64], which was carried out in the Malopolska Province, there is a huge fragmentation of agricultural holdings-this is illustrated by the largest number of record parcels per area of province in Poland. The area of Malopolska covers approximately 1.5 million hectares, with circa 4.5 million record parcels. By comparison, the area of Podlasie (north-eastern Poland) is about 2 million hectares and there are only about 1.5 million record parcels. 
The consequence of such fragmentation of farms is a patchwork of agricultural land and residential areas. This disrupts the functions of proper use of agricultural land resulting in the disappearance of intensive agriculture in Malopolska and the agricultural function is limited to small family farms or agrotouristic farms (preoccupied with the manufacture of traditional products and tourism).

Agricultural production depends on natural conditions such as soil quality, agricultural suitability and susceptibility to water erosion. Agricultural land, especially of higher classes I-II, is invaluable. It is our responsibility to ensure that it does not degrade as a result of unjustified investment decisions.

The results obtained in this research paper are consistent with the results of other analyses that were conducted in Poland but to a limited extent. In the study [65], the analysis covered the period of 2000-2005 but the subject of the study was only one commune of Siedlce. However, the basis for the analyses was primarily the data from the Central Statistical Office and only a small part of the data was derived from the real estate cadastre. These studies have also proved that land converted from agricultural to non-agricultural use is earmarked mainly for housing estates and the most changes have occurred in the immediate vicinity of large cities.

Another study which has analysed changes in the structure of land use in Poland [66]. The research object is one county in the Mazowieckie province. Detailed research has been based on the data from the soil and agricultural maps at the scale of 1:5000 and they have been conducted for one commune of this county only. General research studies, covering the entire county, have been performed based on the soil and agricultural map at the scale of 1:50,000. These studies have demonstrated that a favourable location, proximity to Warsaw and good transport accessibility often result in the land of the highest quality and agricultural usefulness being earmarked for development, as confirmed by the results presented in this research paper.

Research studies carried out in the Olomouc region in the Czech Republic in the years 1991-2001 [67] demonstrated a slightly higher, by approximately 3.5\%, increase in residential areas on arable land than in Malopolska. However, these studies were based on less detailed data from Landsat Thematic Mapper (TM) and Enhanced Thematic Mapper Plus (ETM+) and they concerned land use only.

Contrary to what was stated in the paper [68] with respect to 25 European countries in the years 2000-2006 based on averaged data from Corine Land Cover maps, that subsidies under the common agricultural policy of the European Union could stop the degradation of agricultural land, in the region of Małopolska such degradation has not been stopped. The agricultural land of the best quality classes is permanently being degraded and earmarked for housing purposes, which has been proved in this research paper based on the detailed data from the real estate cadastre.

\section{Conclusions}

Pursuant to Polish legislation, for the conversion of land of classes I-III, landowners are obliged to pay stipulated fees (a one-time fee and annual fees for a period of 10 years, starting from the actual date of conversion of agricultural land to non-agricultural use). These fees, however, are not high enough to dissuade investors. Under the Polish legal regulations, these amounts depend on the price of a ton of rye as a conversion unit per 1 hectare of land permanently converted to non-agricultural use.

Despite the owner being obliged to obtain an administrative decision authorizing the conversion of land to non-agricultural use prior to the construction permit, such a system does not discourage investors. Local authorities allow making such changes in the land use as it increases the revenues of self-governments of the communes, municipalities and counties from real estate taxes. This is the reason why the authorities are friendly in the decision-making process regarding this phenomenon. The richest commune in the Malopolska Province is Wielka Wies (data based on the revenue from real estate taxes per capita), located in the Krakow county.

The studies have demonstrated that of all the counties in the Malopolska Province, the Krakow county faces the largest loss of land of the best quality classes. Undoubtedly, the vicinity of the capital of the province - the city of Krakow—affects the investment attractiveness of the land located around 
it, resulting in the conscious aim of converting it for residential purposes. The most important factor for potential residents of this county is the proximity of a large city and the attractive labour market.

It seems obvious that the areas in the immediate vicinity of large cities are becoming bedroom communities of urban agglomerations. However, it is the responsibility of the local authorities of Malopolska to maintain sustainable development of this region; they should protect areas with the best environmental resources. A possible solution to this difficult problem would be to establish protected areas on coherent complexes of agricultural land of quality classes I and II. According to the Act on the Protection of Agricultural and Forest land, protected areas are not subject to conversion to non-agricultural use; consequently, the process of irreversible degradation of the best quality soils is stopped.

For the land for which protected areas cannot be established due to their small surface areas and large fragmentation, the solution is to make the market price of the land dependent on its quality class. This means that the attribute 'land quality class' should definitely have more weight in the valuation process than is currently the case. A higher price for the agricultural land of the best quality classes and the resulting higher dues and fees associated with their conversion to non-agricultural use, would become a greater barrier for future investors.

These solutions may not be able to completely eliminate the problem of converting the land with the best natural assets to non-agricultural (residential) use. However, they will certainly slow down this process and will help to prevent the degradation of the best areas.

Acknowledgments: Research was funded by the AGH University of Science and Technology in Krakow. This work has been performed as part of scientific research carried out in the Department of Integrated Geodesy and Cartography 11.11.150.444. The authors wish to express their sincere gratitude to the Marshal's Office of the Malopolska Province for providing an access to their databases.

Author Contributions: All persons who meet authorship criteria are listed as authors and all authors certify that they have participated sufficiently in the work to take public responsibility for the content, including participation in the concept, design, analysis, writing, or revision of the manuscript. Furthermore, each author certifies that this material or similar material has not been and will not be submitted to or published in any other publication before. Malgorzata Busko was responsible for the conception and design of the work, analysis and interpretation of data and drafting the article. Beata Szafranska was responsible for the acquisition of data, analysis and interpretation.

Conflicts of Interest: The authors declare no conflict of interest.

\section{Appendix A}

Table A1. Surface area of agricultural land use within specific quality classes in the individual counties of the Malopolska province in 2010.

\begin{tabular}{cccccc}
\hline County No. & County of & Classes I and II (ha) & Class III (ha) & Class IV (ha) & Classes V-VI (ha) \\
\hline 1 & BOCHNIA & 1313 & 10,421 & 9481 & 1950 \\
2 & BRZESKO & 652 & 9611 & 22,178 & 8685 \\
3 & CHRZANOW & 299 & 3739 & 6161 & 6737 \\
4 & DABROWA & 3591 & 7049 & 17,842 & 11,407 \\
5 & GORLICE & 233 & 6309 & 23,625 & 16,040 \\
6 & KRAKOW & 14,987 & 46,977 & 24,681 & 5073 \\
7 & LIMANOWA & 0 & 1113 & 16,897 & 30,839 \\
8 & MIECHOW & 4621 & 31,231 & 14,388 & 4323 \\
9 & MYSLENICE & 37 & 6908 & 14,552 & 13,319 \\
10 & NOWY SACZ & 309 & 6019 & 31,729 & 35,083 \\
11 & NOWY TARG & 7 & 1207 & 23,788 & 84,002 \\
12 & OLKUSZ & 370 & 13,980 & 16,353 & 19,249 \\
13 & OSWIECIM & 1467 & 14,887 & 14,828 & 3235 \\
14 & PROSZOWICE & 27,656 & 25,985 & 5499 & 1250 \\
15 & SUCHA BESKIDZKA & 10 & 793 & 13,690 & 27,870 \\
16 & TARNOW & 10,405 & 28,034 & 72,887 & 25,310 \\
17 & ZAKOPANE & 0 & 16 & 2229 & 19,238 \\
18 & WADOWICE & 782 & 21,550 & 28,254 & 5090 \\
19 & WIELICZKA & 4639 & 25,269 & 9464 & 1717 \\
\hline
\end{tabular}


Table A2. Surface area of the whole agricultural land converted to non-agricultural use in individual counties of the Malopolska province in the years 2010-2016, expressed in hectares (ha).

\begin{tabular}{|c|c|c|c|c|c|c|c|c|}
\hline County No. & County of & 2010 (ha) & 2011 (ha) & 2012 (ha) & 2013 (ha) & 2014 (ha) & 2015 (ha) & 2016 (ha) \\
\hline 2 & BRZESKO & 3.75 & 3.07 & 2.78 & 3.01 & 3.03 & 4.08 & 7.91 \\
\hline 4 & DABROWA & 0.51 & 0.51 & 2.25 & 3.01 & 0.41 & 1.5 & 1.88 \\
\hline 5 & GORLICE & 3.68 & 3.27 & 3.57 & 2.07 & 2.314 & 3.1 & 3.03 \\
\hline 6 & KRAKOW & 69.63 & 57.69 & 68.54 & 60.61 & 58.92 & 69.47 & 84.11 \\
\hline 9 & MYSLENICE & 8.97 & 6.31 & 7.44 & 11.52 & 7.98 & 11.11 & 16.83 \\
\hline 10 & NOWY SACZ & 4.58 & 5.48 & 4.26 & 4.53 & 3.38 & 3.84 & 6.09 \\
\hline 11 & NOWY TARG & 0.93 & 1.07 & 0.71 & 0.67 & 0.6006 & 1.09 & 1.09 \\
\hline 12 & OLKUSZ & 1.12 & 1.31 & 1.79 & 2.05 & 0.84 & 1.56 & 0.91 \\
\hline 13 & OSWIECIM & 5.33 & 6.69 & 7.08 & 5.53 & 7.32 & 16.68 & 18.42 \\
\hline 18 & WADOWICE & 10.46 & 10.21 & 12.2 & 8.8 & 9.71 & 13.79 & 25.94 \\
\hline 19 & WIELICZKA & 20.76 & 20.39 & 21.51 & 17.66 & 22.08 & 33.24 & 52.21 \\
\hline
\end{tabular}

Table A3. Percentage share of the areas of specific quality classes converted for residential purposes in the years 2010-2016 in the counties of the Malopolska province.

\begin{tabular}{cccccc}
\hline County No. & County of & Classes I and II & Class III & Class IV & Classes V-VI \\
\hline 1 & BOCHNIA & 0.404 & 0.362 & 0.048 & 0.000 \\
2 & BRZESKO & 0.035 & 0.168 & 0.000 & 0.000 \\
3 & CHRZANOW & 0.013 & 0.142 & 0.002 & 0.008 \\
4 & DABROWA & 0.009 & 0.046 & 0.026 & 0.000 \\
5 & GORLICE & 0.103 & 0.302 & 0.000 & 0.000 \\
6 & KRAKOW & 0.742 & 0.532 & 0.003 & 0.003 \\
7 & LIMANOWA & 0.000 & 0.214 & 0.000 & 0.000 \\
8 & MIECHOW & 0.040 & 0.019 & 0.000 & 0.000 \\
9 & MYSLENICE & 0.351 & 0.715 & 0.015 & 0.000 \\
10 & NOWY SACZ & 0.706 & 0.485 & 0.000 & 0.000 \\
11 & NOWY TARG & 0.000 & 0.000 & 0.000 & 0.000 \\
12 & OLKUSZ & 0.019 & 0.052 & 0.000 & 0.001 \\
13 & OSWIECIM & 0.178 & 0.217 & 0.001 & 0.024 \\
14 & PROSZOWICE & 0.030 & 0.014 & 0.000 & 0.000 \\
15 & SUCHA BESKIDZKA & 0.000 & 0.468 & 0.000 & 0.000 \\
16 & TARNOW & 0.117 & 0.160 & 0.000 & 0.000 \\
17 & ZAKOPANE & 0.000 & 0.000 & 0.000 & 0.001 \\
18 & WADOWICE & 0.113 & 0.234 & 0.000 & 0.000 \\
19 & WIELICZKA & 0.291 & 0.355 & 0.000 & 0.000 \\
\hline
\end{tabular}




\section{Appendix B}

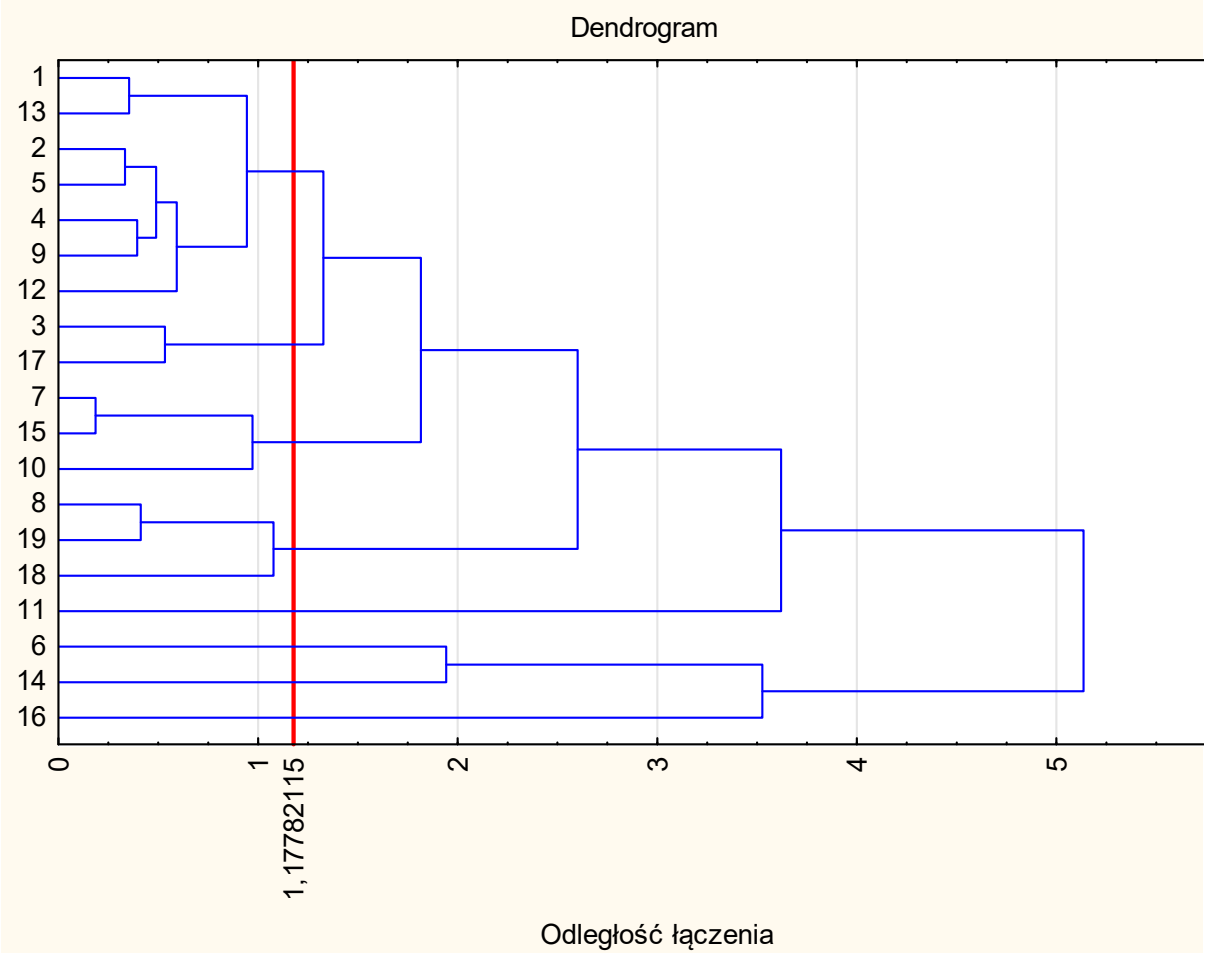

Figure A1. Dendrogram for the bar chart from Figure 4-area of quality classes I-VI in individual counties of the Malopolska province as of 1 January 2010.

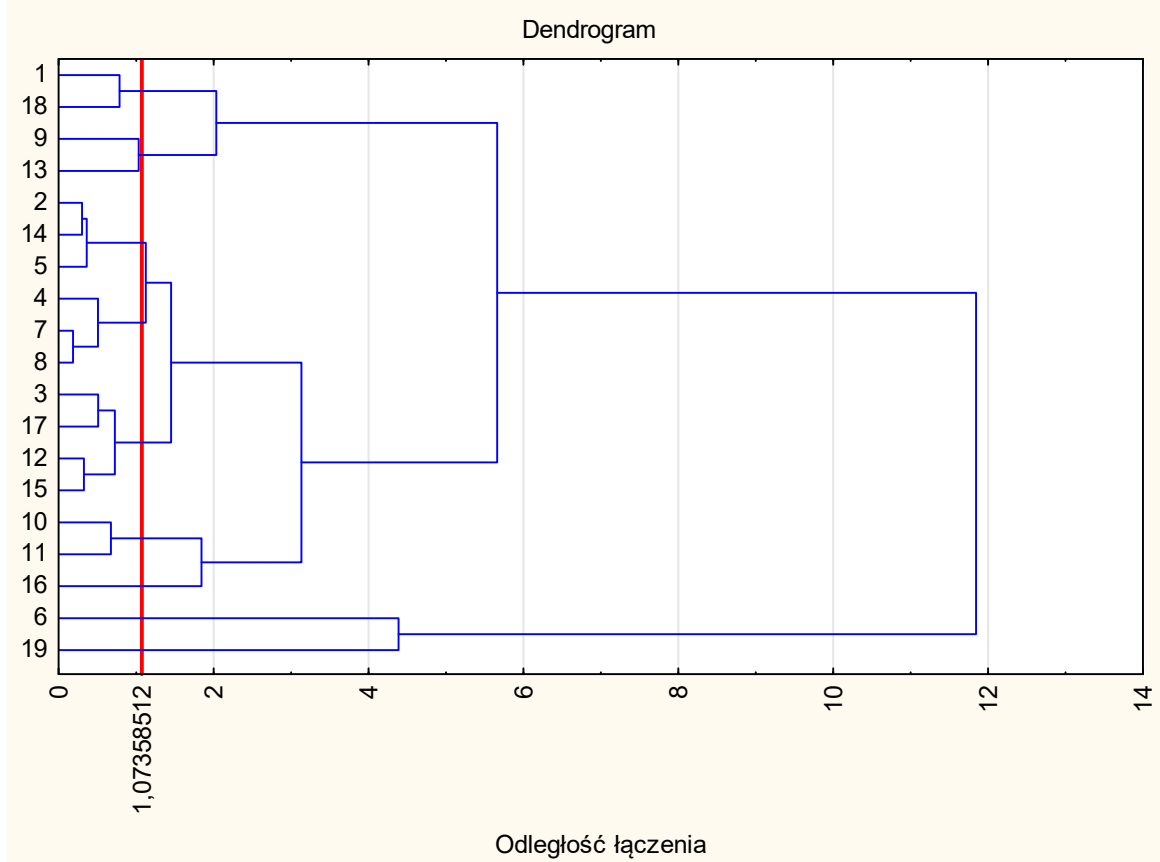

Figure A2. Dendrogram of surface area of the whole agricultural land converted to non-agricultural use in individual counties of the Malopolska province in the years 2010-2016, expressed in percent (\%). 


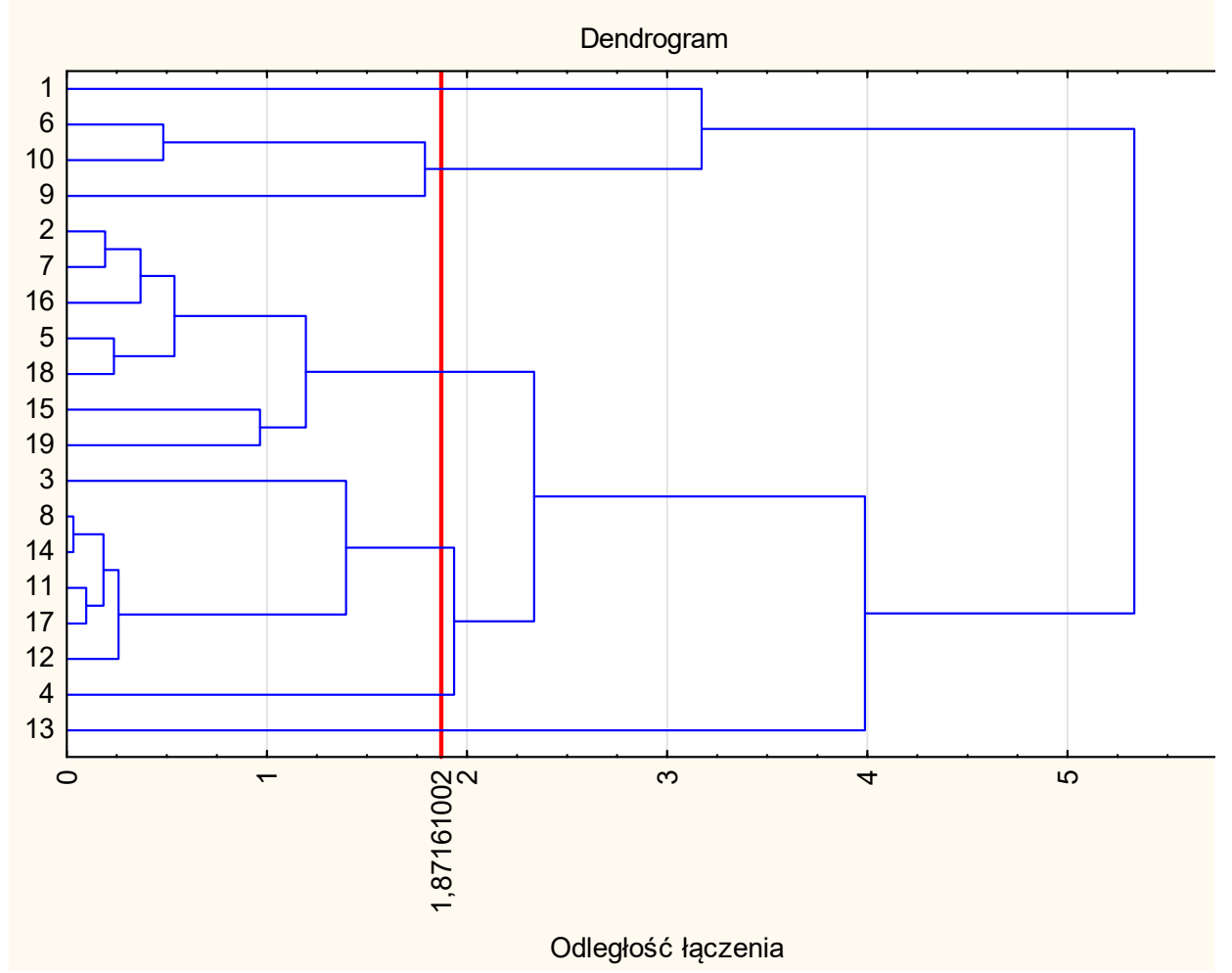

Figure A3. Dendrogram of the percentage share of the areas of specific quality classes converted for residential purposes in the years 2010-2016 in the counties of the Malopolska province.

\section{Appendix C}

The data from the databases of the register of land and buildings maintained by the counties. The data illustrates the general structure of the soil quality classes for the entire province (225 files): https:/ / drive.google.com/open?id=1R3WpSILWlZ7sAekmKLeYwBBA8PzpmWpP.

\section{Appendix D}

Surface area of the whole agricultural land converted to non-agricultural use in individual counties of the Malopolska province in the years 2010-2016 (7 files): https:/ / drive.google.com/open? id=1LEB9Qo9P1KRqBgsxEgfECCB4sEtf5MnE.

\section{References}

1. Act on Environmental Protection of 27 April 2001. Available online: http://prawo.sejm.gov.pl/isap.nsf/ DocDetails.xsp?id=WDU20010620627 (accessed on 25 September 2017).

2. Report of the World Commission on Environment and Development: Our Common Future. Published in 1987. Available online: http://www.un-documents.net/our-common-future.pdf (accessed on 25 September 2017).

3. Dizdaroglu, D. The Role of Indicator-Based Sustainability Assessment in Policy and the Decision-Making. Process: A Review and Outlook. Sustainability 2017, 9, 1018. [CrossRef]

4. Sansoni, M.; Bonazzi, E.; Goralczyk, M.; Stauvermann, P.J. RAMEA: How to support regional policies towards sustainable development. Sustain. Dev. 2010, 18, 202-210. [CrossRef]

5. Dawidowcz, A.; Zrobek, R. Land Administration System for Sustainable Development-Case Study of Poland. Real Estate Manag. Valuat. 2017, 25, 112-122. [CrossRef]

6. Williamson, I.P.; Enemark, S.; Wallace, J.; Rajabifard, A. Land Administration for Sustainable Development; ESRI Press: Redlands, CA, USA, 2010; p. 487. ISBN 978-1-58948-041-4. 
7. Williamson, I.; Bennett, R.; Rajabifard, A.; Wallace, J. Lessons for Federal Countries That Have State Land Registries-The Australian Experience. In Proceedings of the 11th South East Asian Surveyors Conference (SEASC), Kuala Lumpur, Malaysia, 22-24 June 2011.

8. Shen, B.; Lepech, M.D. Probabilistic Design of Environmentally Sustainable Reinforced-Concrete Transportation Infrastructure Incorporating Maintenance Optimization. J. Infrastruct. Syst. 2017, 23. [CrossRef]

9. Diogo, V.; Koomen, E.; Kuhlman, T. An economic theory-based explanatory model of agricultural land-use patterns: The Netherlands as a case study. Agric. Syst. 2015, 139, 1-16. [CrossRef]

10. Head, K.; Ries, J.; Swenson, D. Agglomeration Benefits and Location Choice-Evidence from Japanese Manufacturing Investments in the UNITED-STATES. J. Int. Econ. 1995, 38, 223-247. [CrossRef]

11. Špulerová, J.; Dobrovodská, M.; Izakovičová, Z.; Kenderessy, P.; Petrovič, F.; Štefunková, D. Developing a strategy for the protection of traditional agricultural landscapes based on a complex landscape-ecological evaluation (the case of a mountain landscape in Slovakia). Morav. Geogr. Rep. 2013, 21, 15-26. [CrossRef]

12. Jiang, G.; Ma, W.; Qu, Y.; Zhang, R.; Zhou, D. How does sprawl differ across urban built-up land types in China? A spatial-temporal analysis of the Beijing metropolitan area using granted land parcel data. Cities 2016, 58, 1-9. [CrossRef]

13. Jiang, G.; Ma, W.; Wang, D.; Dingyang, Z.; Ruijuan, Z.; Tao, Z. Identifying the internal structure evolution of urban built-up land sprawl (UBLS) from a composite structure perspective: A case study of the Beijing metropolitan area, China. Land Use Policy 2017, 62, 258-267. [CrossRef]

14. Jiang, G.; He, X.; Qu, Y.; Ruijuan, Z.; Yuan, M. Functional evolution of rural housing land: A comparative analysis across four typical areas representing different stages of industrialization in China. Land Use Policy 2016, 57, 645-654. [CrossRef]

15. Kanianska, R.; Kizekova, M.; Novacek, J.; Zeman, M. Land-use and land-cover changes in rural areas during different political systems: A case study of Slovakia from 1782 to 2006. Land Use Policy 2014, 36, 554-566. [CrossRef]

16. Nowak, A.; Schneider, C. Environmental characteristics, agricultural land use, and vulnerability to degradation in Malopolska Province (Poland). Sci. Total Environ. 2017, 590-591, 620-632. [CrossRef] [PubMed]

17. Bucała-Hrabia, A. From communism to a free-market economy: A reflection of socio-economic changes in land use structure in the Vicinity of the city (beskid sadecki, western Polish carpathians). Geogr. Polonica 2017, 90, 65-79. [CrossRef]

18. Mazzocchi, C.; Corsi, S.; Sali, G. Agricultural Land Consumption in Periurban Areas: A Methodological Approach for Risk Assessment Using Artificial Neural Networks and Spatial Correlation in Northern Italy. Appl. Spat. Anal. Policy 2017, 10, 3-20. [CrossRef]

19. Ceccarelli, T.; Bajocco, S.; Perini, L.L.; Salvati, L. Urbanisation and land take of high quality agricultural soils-Exploring long-term land use changes and land capability in Northern Italy. Int. J. Environ. Res. 2014, $8,181-192$.

20. Van Vliet, J.; de Groot, H.L.F.; Rietveld, P.; Verburg, P.H. Manifestations and underlying drivers of agricultural land use change in Europe. Landsc. Urban Plan. 2015, 133, 24-36. [CrossRef]

21. Act on the Protection of Agricultural and Forest Land of 3 February 1995. Available online: http:/ / prawo. sejm.gov.pl/isap.nsf/DocDetails.xsp?id=WDU19950160078 (accessed on 25 September 2017).

22. Busko, M.; Kolinska, M. Issues related to exclusion of arable lands, located within borders of urban areas, from the agricultural production after updating of legal regulations. Przeglad Geodezyjny 2015, 3, 7-13. [CrossRef]

23. Bielska, A.; Turek, A. Analysis of the needs for updates of the land and building register considering the procedure of exclusion of agricultural land from production. Infrastruct. Ecol. Rural Areas 2016, 1633-1644. [CrossRef]

24. Salata, T.; Prus, B.; Janus, J. Planning as trigger for land use changes. Eng. Rural Dev. 2015, 14, 729-734.

25. Fang, Y.; Cote, R.P.; Qin, R. Industrial sustainability in China: Practice and prospects for eco-industrial development. J. Environ. Manag. 2007, 83, 315-328. [CrossRef] [PubMed]

26. Funderburg, R.G.; Zhou, X. Trading industry clusters amid the legacy of industrial land-use planning in southern California. Environ. Plan. A 2013, 45, 2752-2770. [CrossRef] 
27. Gebeyehu, A.T. Urban land use dynamics, the nexus between land use pattern and its challenges: The case of Hawassa city, Southern Ethiopia. Land Use Policy 2015, 45, 159-175. [CrossRef]

28. Lai, Y.; Peng, Y.; Li, B.; Lin, Y. Industrial land development in urban villages in China: A property rights perspective. Habitat Int. 2014, 41, 185-194. [CrossRef]

29. Li, D.; Zhang, C.; Pizzol, L.; Critto, A.; Zhang, H.; Lv, S.; Marcomini, A. Regional risk assessment approaches to land planning for industrial polluted areas in China: The Hulunbeier region case study. Environ. Int. 2014, 65, 16-32. [CrossRef] [PubMed]

30. Li, J.; Zhang, W.; Chen, H.; Yu, J. The spatial distribution of industries in transitional China: A study of Beijing. Habitat Int. 2015, 49, 33-44. [CrossRef]

31. Kaliszewski, A.; Mlynarski, W.; Golos, P. Factors limiting afforestation of post-agricultural lands in Poland according to the survey results. Sylwan 2016, 160, 846-854.

32. Bieda, A.; Jasinska, E.; Preweda, E. Surveying Protection of Agricultural Land in Poland. In Proceedings of the 9th International Conference on Environmental Engineering (ICEE), Vilnius, Lithuania, 22-23 May 2014. [CrossRef]

33. Marks-Bielska, R.; Zukovskis, J. Conditions of Changes in the Agricultural Land Market in Poland during the Years 1992-2009: Background for Systematic Research. In Proceedings of the 5th International Scientific Conference on Rural Development, Aleksandras Stulginskis University, Akademija, Lithuania, 24-25 November 2011.

34. Just, D.R.; Kropp, J.D. Production incentives from static decoupling: Land use exclusion restrictions. Am. J. Agric. Econ. 2013, 95, 1049-1067. [CrossRef]

35. Tarasovičová, Z.; Saksa, M.; Blažík, T.; Falt’an, V. Changes in agricultural land use in the context of ongoing transformational processes in Slovakia. Agriculture 2013, 59, 49-64. [CrossRef]

36. Labarthe, P.; Laurent, C. Service economics and public policies for agricultural extension. Cah. Agric. 2011, 20, 343-351.

37. Balawejder, M.; Wójciak, E. Application of gis tools in analysing a road network providing access to cadastral parcels in the project concerning land consolidation and exchange. In Proceedings of the Geographic Information Systems Conference and Exhibition “GIS ODYSSEY 2017”, Trento, Vattaro, Italy, 4-8 September 2017.

38. Du, P.; Wood, A.; Ditchman, N.; Stephens, B. Life Satisfaction of Downtown High-Rise vs. Suburban Low-Rise Living: A Chicago Case Study. Sustainability 2017, 9, 1052. [CrossRef]

39. Ruan, X.; Qiu, F.; Dyck, M. The effects of environmental and socioeconomic factors on land-use changes: A study of Alberta, Canada. Environ. Monit. Assess. 2016, 188, 446. [CrossRef] [PubMed]

40. Kim, J.J.; Goodwin, C.W.; Kim, S. Communication turns green construction planning into reality. J. Green Build. 2017, 12, 168-186. [CrossRef]

41. Fritz-Vietta, N.V.M.; Tahirindraza, H.S.; Stoll-Kleemann, S. Local people's knowledge with regard to land use activities in southwest Madagascar-Conceptual insights for sustainable land management. J. Environ. Manag. 2017, 199, 126-138. [CrossRef] [PubMed]

42. Murgida, A.M.; Gonzalez, M.; Tiessen, H. Rainfall trends, land use change and adaptation in the Chaco salteo region of Argentina. Reg. Environ. Chang. 2014, 14, 1387-1394. [CrossRef]

43. Jiang, G.; Ma, W.; Zhou, D.; Zhao, Q.; Zhang, R. Agglomeration or dispersion? Industrial land-use pattern and its impacts in rural areas from China's township and village enterprises perspective. J. Clean. Prod. 2017, 159, 207-219. [CrossRef]

44. Li, Y.; Hu, Z. Approaching Integrated Urban-Rural Development in China: The Changing Institutional Roles. Sustainability 2015, 7, 7031-7048. [CrossRef]

45. Bishai, M.F. The Development of Industrial Land in Taiwan-A Legal Framework for State Control. J. Dev. Areas 1991, 26, 53-64.

46. Byrd, W.A.; Li, Q. China's Rural Industry: Structure, Development, and Reform; A World Bank Research Publication; Oxford University Press: New York, NY, USA, 1990; ISBN 0-19-520822-6.

47. Choy, L.H.T.; Lai, Y.; Lok, W. Economic performance of industrial development on collective land in the urbanization process in China: Empirical evidence from Shenzhen. Habitat Int. 2013, 40, 184-193. [CrossRef]

48. Hakizimana, C.; Goldsmith, P.; Nunow, A.A.; Roba, A.W.; Biashara, J.K. Land and agricultural commercialisation in Meru County, Kenya: Evidence from three models. J. Peasant Stud. 2017, 44, 555-573. [CrossRef] 
49. Siejka, M. Public Purpose Investments Site Selection in Real Estate Management—Case Study in Poland. In Proceedings of the 16th International Multidisciplinary Scientific Geo Conference SGEM, Albena, Bulgaria, 28 June-6 July 2016; pp. 503-509.

50. Lausch, A.; Blaschke, T.; Haase, D.; Herzog, F.; Syrbe, R.U.; Tischendorf, L.; Walz, U. Understanding and quantifying landscape structure-A review on relevant process characteristics, data models and landscape metrics. Ecol. Model. 2015, 295, 31-41. [CrossRef]

51. Regulation of the Minister of Regional Development and Construction of 15 July 2016 on the Register of Land and Buildings. Available online: http:/ / prawo.sejm.gov.pl/isap.nsf/DocDetails.xsp?id=WDU20160001034 (accessed on 25 September 2017).

52. Statistical Office in Cracow. Agriculture in Malopolskie Voivodship in 2015 Information and Statistics; Statistical Office in Cracow: Krakow, Poland, 2016.

53. Litwin, U.; Szafranska, B. Using GIS in Management and Agricultural Surveying in the Malopolska Province; Agricultural University: Krakow, Poland, 2017.

54. Baczwarow, M.; Suliborski, A. The Compendium of Knowledge about Political Geography and Geopolitics; Terminology; Polish Scientific Publishers: Warsaw, Poland, 2002.

55. Czekanowski, J. The Outline of Statistical Methods In application to Anthropology; Works of the Warsaw Scientific Society: Warsaw, Poland, 1913.

56. Kukula, K. Statistical Methods for Analysis of Economic Structures; Educational Publishing House: Krakow, Poland, 1996.

57. Mlodak, A. Taxonomic Analysis in Regional Statistics; Difin: Warsaw, Poland, 2006.

58. Gatnar, E. Symbolic Methods of Data Classification; Polish Scientific Publishers: Warsaw, Poland, 1998.

59. Stanisz, A. Intelligible Statistics Course Using STATISTICA PL on Medical Examples; StatSoft Poland: Krakow, Poland, 2007.

60. Wezyk, P.; Wojtowicz-Nowakowska, A.; Pierzchalski, M.; Mlost, J.; Szafranska, B. Map of land cover changes in Malopolska in 1986-2011 based on object classification of satellite images LANDSAT and RapidEye. Photogramm. Cartogr. Remote Sens. Arch. 2013, 25, 273-284.

61. Lowicki, D. Land use changes in Poland during transformation. Case study of Wielkopolska region. Landsc. Urban Plan. 2008, 87, 279-288. [CrossRef]

62. Kocur-Bera, K. Farmer's perception of agricultural land after accesion to the EU-A case study. In Proceedings of the 2016 International Conference, Economic Scince for Rural Development, Llu Esaf, Jelgava, Latvia, December 2016-April 2017.

63. Kocur-Bera, K. Determinants of Agricultural Land Price in Poland-A Case Study Covering A Part of the EuroRegion Baltic. Cah. Agric. 2016, 25, 25004. [CrossRef]

64. Busko, M.; Meusz, A. Current status of real estate cadastre in Poland with reference to historical conditions of different regions of the country. In Proceedings of the 9th International Conference Environmental Engineering, Vilnius, Lithuania, 22-23 May 2014.

65. Bielecka, E.; Calka, B. The Analysis of the Land Exclusions from Agricultural and Forest Production in the Rural Areas. Available online: http:/ /yadda.icm.edu.pl/yadda/element/bwmeta1.element.agro-48516e321887-4944-bdf6-d6962f0e5a40 (accessed on 25 September 2017).

66. Bielska, A.; Turek, A.; Maciejewska, A.; Bozym, K. Problems of agricultural land protection in suburbanization process. Infrastruct. Ecol. Rural Areas 2015, 1035-1045. [CrossRef]

67. Václavík, T.; Rogan, J. Identifying Trends in Land Use/Land Cover Changes in the Context of Post-Socialist Transformation in Central Europe: A Case Study of the Greater Olomouc Region, Czech Republic. GISci. Remote Sens. 2006, 46, 54-76. [CrossRef]

68. Ustaoglu, E.; Williams, B. Determinants of Urban Expansion and Agricultural Land Conversion in 25 EU Countries. Environ. Manag. 2017, 60, 717-746. [CrossRef] [PubMed]

(C) 2018 by the authors. Licensee MDPI, Basel, Switzerland. This article is an open access article distributed under the terms and conditions of the Creative Commons Attribution (CC BY) license (http:/ / creativecommons.org/licenses/by/4.0/). 